\title{
COLLECTING HISTORY AND DISTRIBUTION OF THE POTENTIALLY INVASIVE DISA BRACTEATA (SOUTH AFRICAN ORCHID) IN TASMANIA
}

\author{
by Mark Wapstra, Matthew L. Baker and Grant D. Daniels
}

(with two text-figures, five plates and one table)

\begin{abstract}
Wapstra, M., Baker, M.L. \& Daniels, G.D. 2020 (9:xii): Collecting history and distribution of the potentially invasive Disa bracteata (South African orchid) in Tasmania. Papers and Proceedings of the Royal Society of Tasmania 154: 51-60.

https://doi.org/10.26749/rstpp.154.51 ISSN: 0080-4703. Environmental Consulting Options Tasmania, Lenah Valley, Tasmania 7008, Australia (MW*); Tasmanian Herbarium, Tasmanian Museum and Art Gallery, Sandy Bay, Tasmania 7005, Australia (MLB); North Barker Ecosystem Services, Hobart, Tasmania 7000, Australia (GDD). *Author for correspondence. Email: mark@ecotas.com.au

The collecting history of Disa bracteata Sw. (South African orchid) in Tasmania (Australia), the state's only naturalised member of the Orchidaceae family, is presented. Details of its distribution in Tasmania, since it was first discovered in 2005, are included and discussed with information on habitat, abundance and management. The species is primarily distributed across the north coast (Smithton to Musselroe) with an outlier in Huonville in the state's south. Most sites are from verges along public roads and highways, but the species has also been detected on several private properties and other less disturbed habitats. Many sites with the species have been actively managed with the objective of eradication, although some sites are now well-established so eradication will require concerted effort. It is recommended that the species be added to the Tasmanian Weed Management Act 1999 as a declared species with the primary objective of eradication.
\end{abstract}

Key Words: Disa bracteata, Orchidaceae, distribution, naturalised, weed, invasive.

\section{INTRODUCTION}

The Orchidaceae family is extremely widespread and diverse, with an almost cosmopolitan distribution, and its species can be found growing in a wide range of habitats except for the most arid. It is one of the largest plant families, with estimates suggesting it contains up to 30,000 species (Mabberley 2008, Chen et al. 2009). Being such a large group of plants, it is surprising that its members are relatively uncommon as naturalised species (e.g. Ackerman 2007). For example, of the nearly 1,400 species that are recorded in China, only one is considered to be naturalised (Chen et al. 2009); and of New Zealand's ca. 117 species, only three are considered to be naturalised (Gardner \& de Lange 1996, Howell \& Sawyer 2006, Breitwieser etal. 2018). A similar pattern occurs in Australia, where a small number of species (Arundina graminifolia (D.Don) Hochr., Disa bracteata, Epidendrum sp., Eulophia graminea Lindl., Serapias neglecta De Not., Vanilla planifolia Jacks. ex Andrews) are reported to have become naturalised, compared to some 1,300 native species (Jones 2006, Clements \& Jones 2008, Conran et al. 2011). In most cases, these are localised occurrences of species that have escaped cultivation (Jones 2006). The subject of this paper, $D$. bracteata, is widely naturalised in parts of southern Australia and is far more capable of self-establishment and long-distance dispersal than any other introduced orchid.

The genus Disa Bergius contains over 160 species and is naturally distributed in sub-Saharan Africa, the Arabian Peninsula, Madagascar and the Mascarene Islands (Leistner 2000, Goldblatt \& Manning 2000, Mabberley 2008). The highest diversity for the genus occurs in southern Africa, with 131 species (Leistner 2000).

Disa bracteata (plate 1, plate 2) is endemic to South Africa where it is widespread and common throughout the highly diverse fynbos that extends across the Western Cape and Eastern Cape provinces (Linder 1981). In its natural range it grows in undisturbed and disturbed habitats but is most frequent and abundant in areas of disturbance such as neglected pasture, roadsides and wasteland where it is considered a pioneer species (Linder 1981). It has been recorded in a wide range of habitats, including those with light and heavy soils, from sea level to 1,500 m a.s.l., grows in full sun or shade and tolerates a wide range of rainfall regimes (Linder 1981). The species is a deciduous perennial geophyte that grows up to $40 \mathrm{~cm}$ tall. Each plant produces numerous leaves and a single, stout, cylindrical flowering spike. It dies back in summer and overwinters as a pair of fleshy tubers. The species flowers from late spring through summer. The self-pollinating flowers produce prodigious quantities of minute seed (Jones 2006) that are readily spread over long distances primarily via wind, but also through other vectors such as contaminated soil on vehicles. The tubers produce numerous fleshy roots that make uprooting entire plants by hand almost impossible in all but the sandiest of soils (M. Wapstra pers. obs.).

With its broad tolerance to a wide range of habitats, prolific seed production and its success as a pioneer species, it was perhaps not surprising that $D$. bracteata became widely naturalised in Australia (fig. 1), one of many plant species from South Africa to have successfully done so (e.g. Scott \& Delfosse 1992, Scott \& Panetta 1993). Jones (2006) noted that its introduction to Australia remains a mystery, with anecdotal statements suggesting that it arrived in Australia on ships from South Africa in the eighteenth century. Several species, and horticulturally derived hybrids of Disa, are cultivated for their ornamental appeal (Synge 1977). However, D. bracteata is purported to not be widely used in horticulture. It was first detected in Australia in 1944 from the rural district of Youngs Siding, near the port city of Albany, in Western Australia. At the time it was thought 

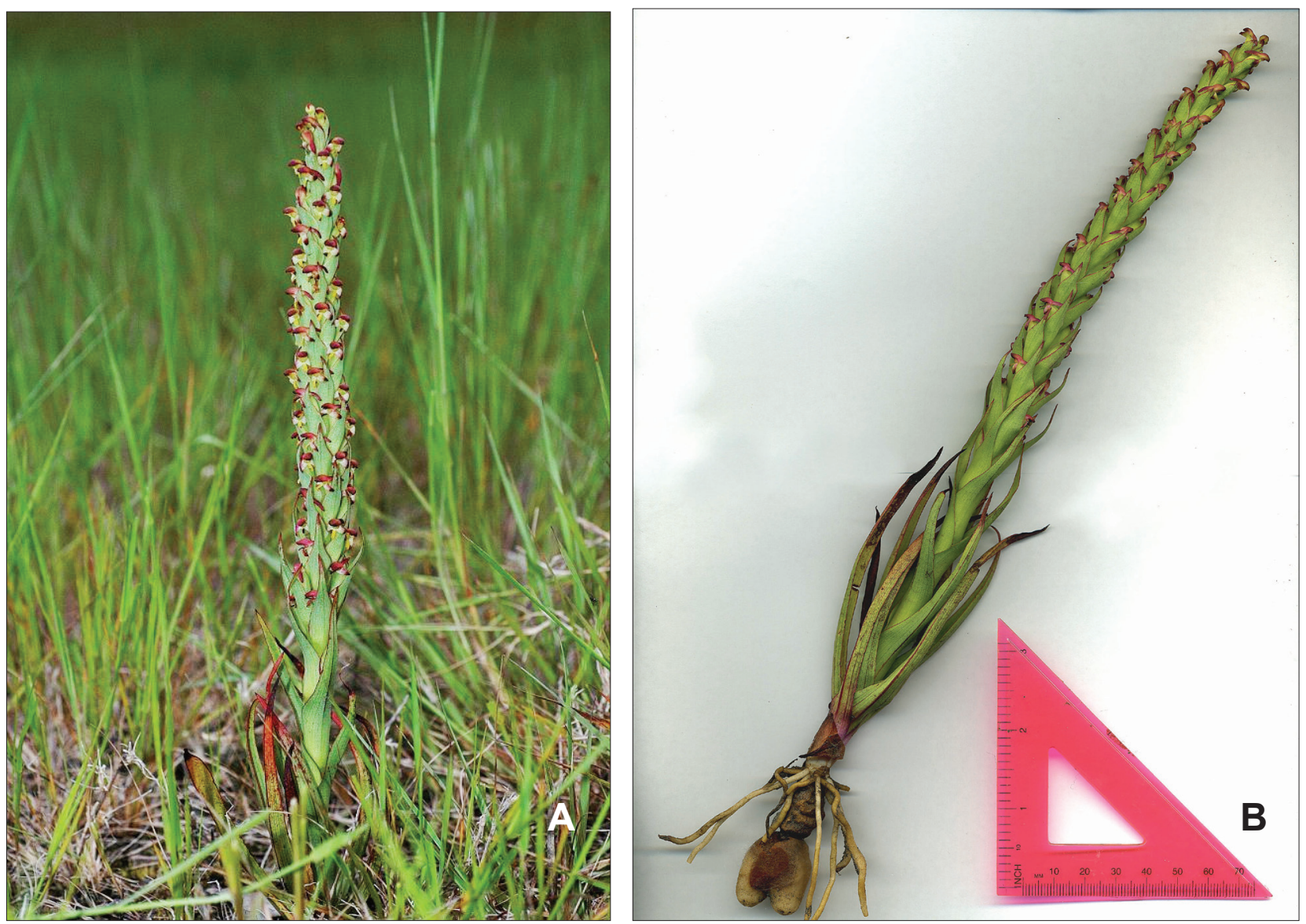

PLATE 1 - Disa bracteata (A) in situ at Latrobe site and (B) excavated (below) (Image: P. Tonelli)

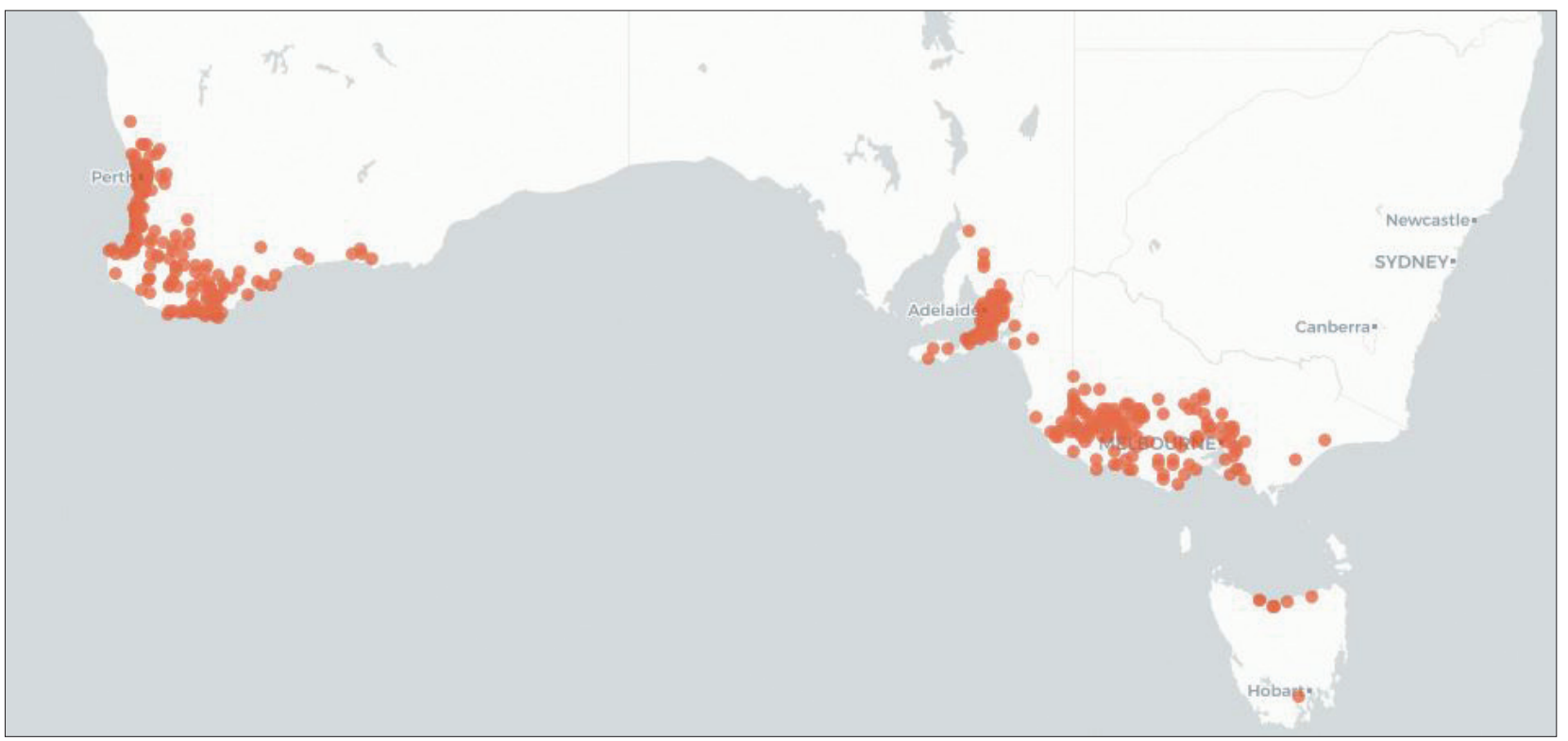

FIG. 1 - Distribution of Disa bracteata in Australia (source: Atlas of Living Australia, 8 August 2020). 

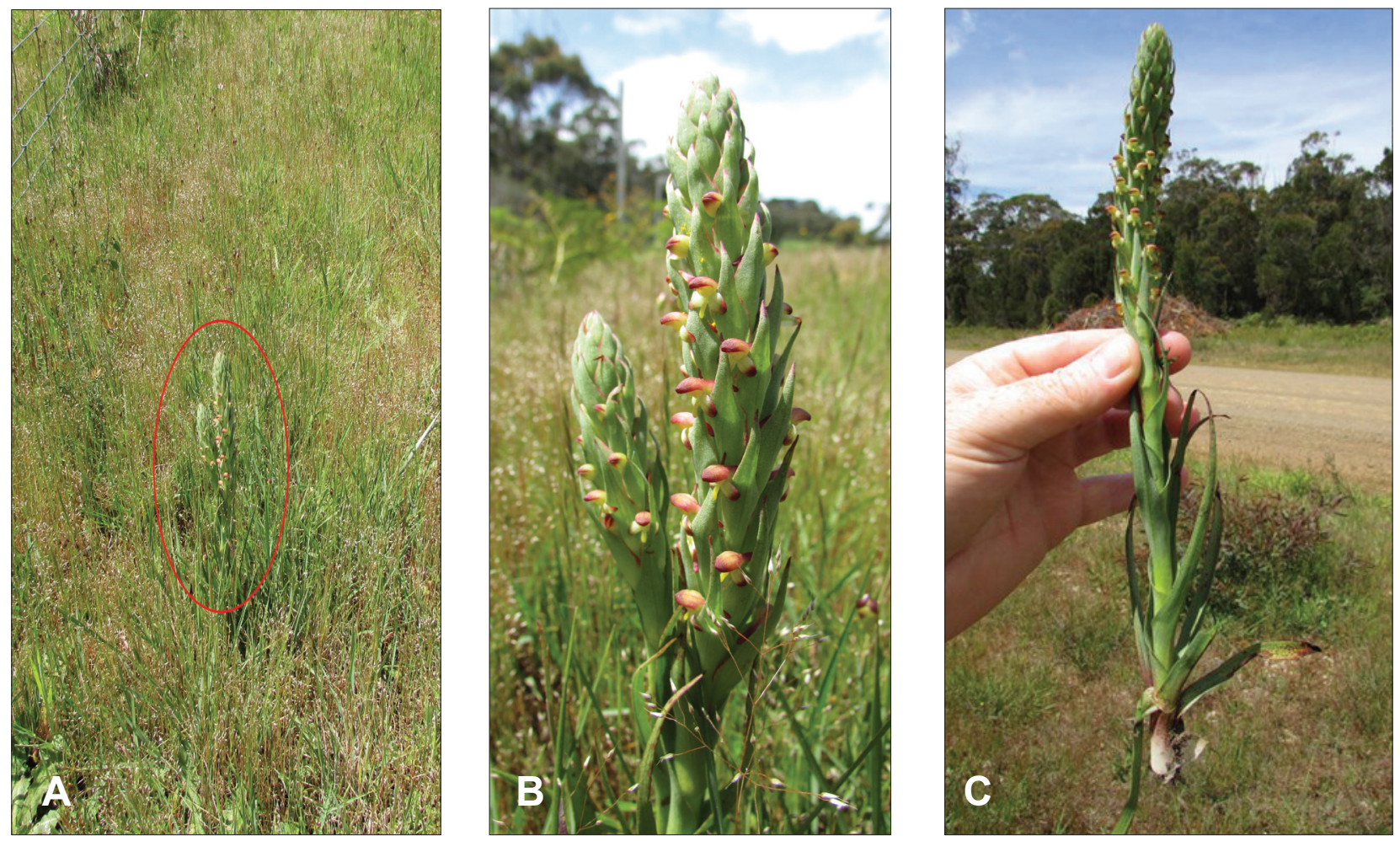

PLATE 2 - (A) Clump of Disa bracteata in situ on Badgers Head Road, (B) close-up image of whole plant, and (C) hand-pulled plant showing lack of tubers and roots, which have remained embedded in the ground. (Images: M. Wapstra)

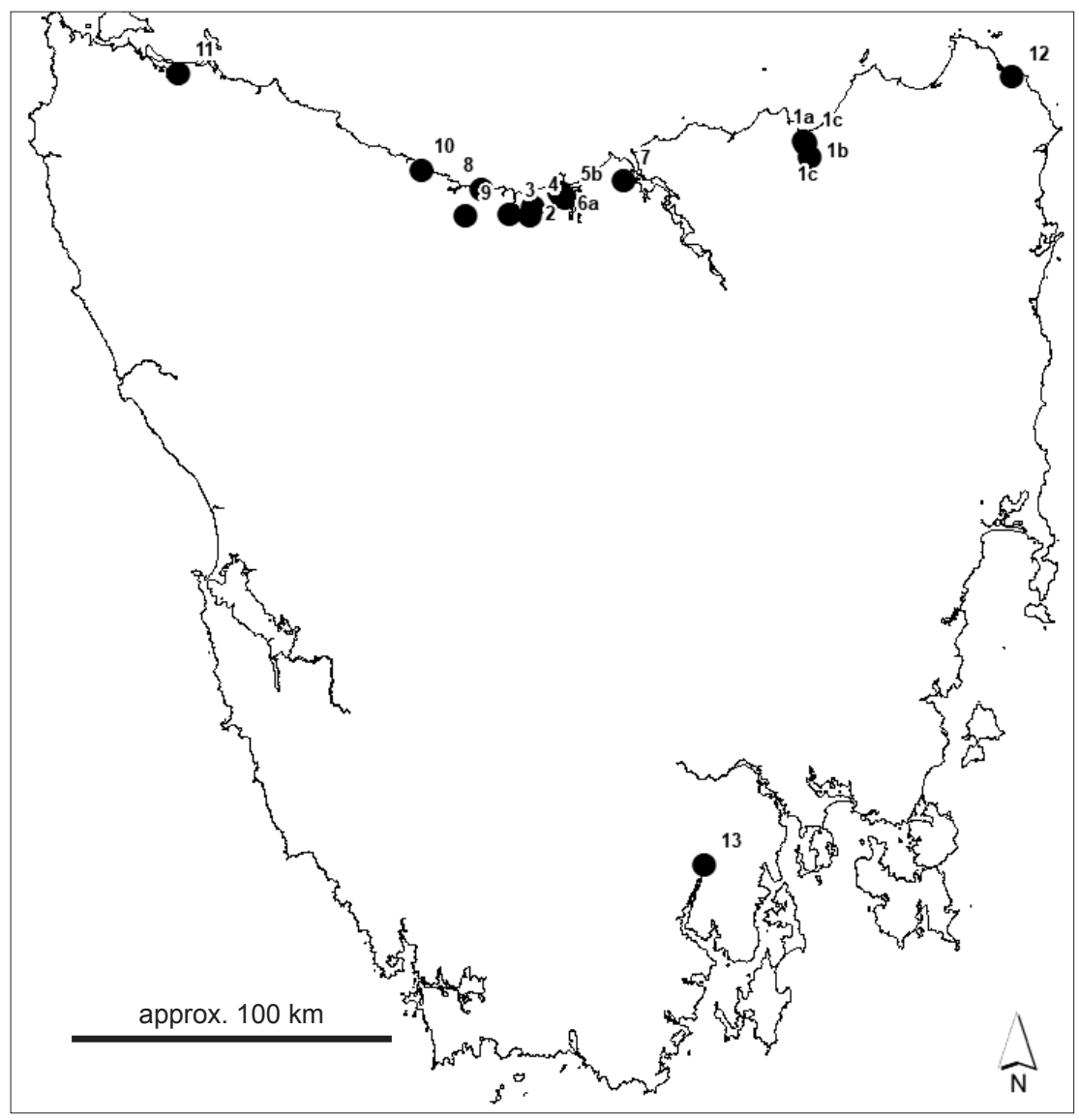

FIG. 2 - Distribution of Disa bracteata in Tasmania (numbers cross-reference to table 1). 
to be a newly recorded native species and was described as Monadenia australiense Rupp (Rupp 1947). Since its discovery, it has become widely naturalised in southwestern Western Australia between Cervantes and Esperance. In South Australia, where it was first discovered in 1988, it is most common in and around the Adelaide Hills area, through to the Fleurieu Peninsula and Kangaroo Island, and around Mt Gambier. In Victoria, the species was first formally recorded in 1994 and is now widespread across southwestern Victoria and eastern parts of Gippsland. The only other region of Australia where it occurs is in Tasmania, where it was first detected in 2005 from a roadside near Bridport in the state's northeast. In Australia, D. bracteata is commonly referred to as the 'South African orchid' or 'African weed-orchid'.

In Western Australia, South Australia and Victoria $D$. bracteata is regarded as a significant environmental weed with a propensity to spread and invade bushland (Richardson et al. 2016), although there is little empirical evidence that shows it has a serious negative ecological impact. In Tasmania, the species is still in the early stages of establishment but with the recent discovery of new populations, the purpose of this paper is to document its current extent of occurrence, identify areas potentially at risk of invasion and describe how weed management legislation may aid in eradication efforts.

\section{METHOD}

\section{Database and collection review}

Several sources of records of native plants were interrogated and reviewed to produce a complete list of all known locations of $D$. bracteata in Tasmania. These were as follows: collections

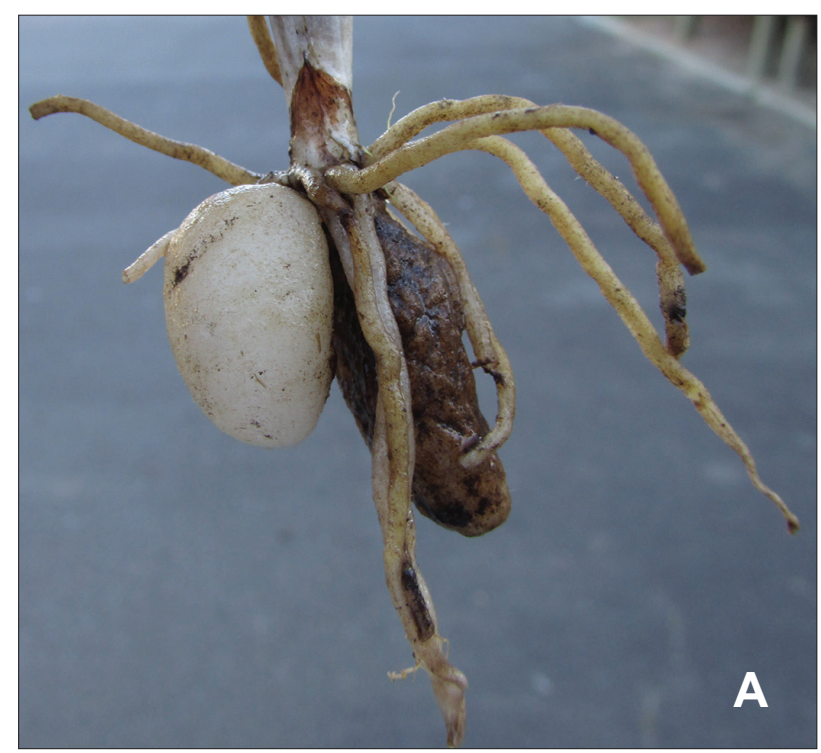

PLATE 3 - Examples of excavated plants showing tubers.

(A) Badger Head Road, October 2015; (B) Bass Highway, March 2016). (Images: M. Wapstra) at the Tasmanian Herbarium, Tasmanian Museum \& Art Gallery (HO); Department of Primary Industries, Parks, Water \& Environment's Natural Values Atlas database (NVA, DPIPWE 2020); Atlas of Living Australia (ALA 2020); the Australasian Virtual Herbarium (AVH 2020); public Facebook groups Tasmanian Native Orchids, Tasmanian Weeds, Tasmanian Flora and Field Naturalists of Tasmania (with several 'posters' contacted direct for additional information); and iNaturalist (with the search terms 'Disa' and 'South African orchid') (www.inaturalist.org, accessed 19 August 2002).

The data were 'cleaned' to produce a definitive worksheet of known locations of the species. 'Cleaning' included removal of obvious database duplicates; removal of records lacking sufficient information to precisely place the site, and shifting of point locations to more precise sites where sufficient information was provided (e.g. records currently shown in the sea were shifted to a nearby terrestrial location if collection notes indicated an obvious location). Data were managed in Excel and transferred to ArcGIS for review.

\section{Field survey}

Field surveys were opportunistic by the authors as part of other ecological assessments or undertaken by the observers noted in table 1 (and information gathered through personal communications). The intent of field surveys was to document abundance and extent, as well as persistence potential and threat to adjacent native vegetation (if present).

Where practical, observed plants were removed by trowel (to gather the tuber and root system), bagged and removed from the site. Some specimens were curated to create voucher collections for the Tasmanian Herbarium and several sites were visited on numerous occasions (noted in table 1).

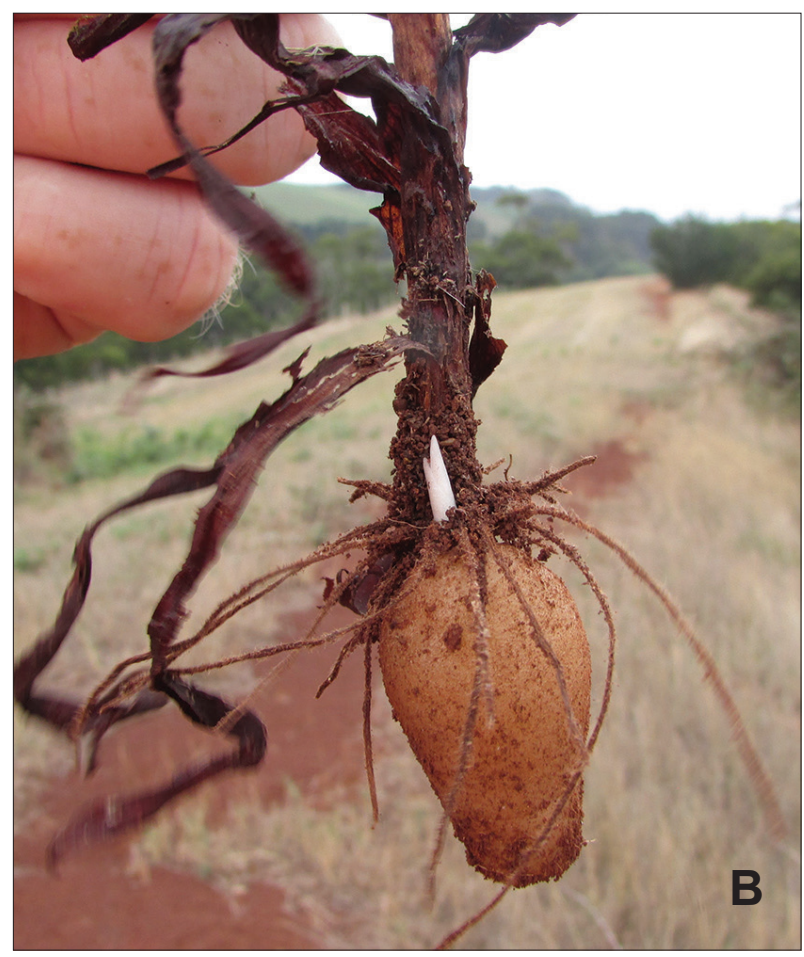


TABLE 1 - Collection details of all Tasmanian populations of Disa bracteata.

\begin{tabular}{|c|c|c|c|}
\hline Site No. ${ }^{1}$ & Location $^{2}$ & Details $^{3}$ & Comments \\
\hline 1a & $\begin{array}{l}\text { "Bridport Road, } 4 \mathrm{~km} \mathrm{SE} \\
\text { of Bridport" }\end{array}$ & $\begin{array}{l}\text { T: State Growth } \\
\text { I: Flinders } \\
\text { M: Dorset } \\
\text { N: North }\end{array}$ & $\begin{array}{l}14 \text { Nov. 2005, HO536631, A. Jungalwalla \& D. Farmery. } \\
\text { "Roadside verge" (from HO536631). } \\
\text { This is the first formal collection of D. bracteata from Tasmania. } \\
\text { Unfortunately, at the time of collection there was confusion as to } \\
\text { whether the specimen had been collected from Bridport Road or } \\
\text { Greens Beach Road, but the collectors have indicated that Bridport } \\
\text { Road is the most likely. Further discussions indicated that they had } \\
\text { "recalled several plants" although only one was submitted. "On } 6 \\
\text { Dec. 2005, the site was surveyed by Alan Gray, Alex Buchanan and } \\
\text { Matthew Baker from the Tasmanian Herbarium along with Jamie } \\
\text { Cooper, the North East Regional Weed Officer. The species in } \\
\text { question was not found" (from HO536631). }\end{array}$ \\
\hline $1 b$ & Bridport Road & $\begin{array}{l}\text { T: State Growth } \\
\text { I: Flinders } \\
\text { M: Dorset } \\
\text { N: North }\end{array}$ & $\begin{array}{l}2 \text { Mar. 2016, no specimen, A. North. } \\
\text { Single, seasonally dead, roadside plant on Bridport Main Road } \\
\text { between Bridport and Scottsdale near junction with Duncraggen } \\
\text { Road; in a scattered infestation of spanish heath sprayed in January; } \\
\text { "unfortunately looks like it has shed seed" (A. North pers. comm.). } \\
\text { This is effectively the same site as the original population (1a). }\end{array}$ \\
\hline $1 \mathrm{c}$ & Bridport Road & $\begin{array}{l}\text { T: State Growth } \\
\text { I: Flinders } \\
\text { M: Dorset } \\
\text { N: North }\end{array}$ & $\begin{array}{l}17 \text { Dec. } 2017 \text {, no specimen, K. Ziegler. } \\
\text { Nine point-locations representing } 68 \text { individuals, most fertilised } \\
\text { and gone to seed, with some plants pulled up (K. Ziegler pers. obs.). } \\
\text { This indicates a significant proliferation of the original population } \\
\text { (1a). } \\
20 \text { Dec. } 2018 \text {, no specimen, A. Williams. } \\
500 \pm 110 \text { individuals on west side of Bridport Road, plants } \\
\text { predominantly located on flat area of road reserve above batter. } \\
50 \pm \text { individuals on east side of Bridport Road. Population is } \\
\text { approximately } 1.1 \mathrm{~km} \text { north of Boddington Road. Plants hand } \\
\text { pulled. }\end{array}$ \\
\hline $1 d$ & Bridport Road & $\begin{array}{l}\text { T: State Growth } \\
\text { I: Flinders } \\
\text { M: Dorset } \\
\text { N: North }\end{array}$ & $\begin{array}{l}17 \text { Dec } 2017 \text {, no specimen, K. Ziegler. } \\
\text { Single plant, seed shedding, hand pulled. } \\
20 \text { Dec. 2018, no specimen, A. Williams } \\
\text { Six individuals, hand pulled. } \\
\text { Site located west side of Bridport Rd, } 730 \text { m north of Boddington } \\
\text { Road. }\end{array}$ \\
\hline $1 \mathrm{c} \& 1 \mathrm{~d}$ & Bridport Road & $\begin{array}{l}\text { T: State Growth } \\
\text { I: Flinders } \\
\text { M: Dorset } \\
\text { N: North }\end{array}$ & $\begin{array}{l}8 \text { Dec. } 2019 \text {, no specimen, J. Cooper. } \\
58 \text { individuals at sites } 1 \mathrm{c} \& 1 \mathrm{~d} \text {. Plants hand pulled. Sites } 1 \mathrm{c} \& 1 \mathrm{~d} \\
\text { surveyed together, including area of road reserve between sites. (J. } \\
\text { Cooper pers. comm.). }\end{array}$ \\
\hline 2 & $\begin{array}{l}\text { "Latrobe, council- } \\
\text { maintained waste site" }\end{array}$ & $\begin{array}{l}\text { T: Local government } \\
\text { I: Flinders } \\
\text { M: Latrobe } \\
\text { N: Cradle Coast }\end{array}$ & $\begin{array}{l}12 \text { Nov. } 2009 \text {, HO559795, P.Tonelli. } \\
\text { "In-fill wasteland; introduced grasses and pasture weeds, some low } \\
\text { quality prostrate native plants (e.g. Hibbertia procumbens) in W end } \\
\text { close to collection site. Only a single specimen located [excavated]; } \\
\text { an extensive search of the local area failed to locate any others" } \\
\text { (from HO559795). Refer to Plate } 1 .\end{array}$ \\
\hline 3 & "Spreyton/Tarleton area" & $\begin{array}{l}\text { T: Private } \\
\text { I: Flinders } \\
\text { M: Latrobe } \\
\text { N: Cradle Coast }\end{array}$ & $\begin{array}{l}8 \text { Nov. 2016, HO586101, G. Pocknee. } \\
\text { "Semi-rural 3-acre block, front weedy lawn - sparsely grassed area } \\
\text { with mosses and weeds; } 5 \text { plants" (from HO586101). } \\
\text { "Still finding the occasional one \& destroying" (Tasmanian Native } \\
\text { Orchids Facebook page, G. Pocknee, } 20 \text { Nov. 2019). }\end{array}$ \\
\hline 4 & Settlers Road, Latrobe & $\begin{array}{l}\text { T: Private } \\
\text { I: Flinders } \\
\text { M: Latrobe } \\
\text { N: Cradle Coast }\end{array}$ & $\begin{array}{l}20 \text { Nov. 2019, no specimen, Tasmanian Native Orchids Facebook } \\
\text { page, BJ Green. }\end{array}$ \\
\hline $5 \mathrm{a}$ & $\begin{array}{l}\text { Parkers Ford Road, Port } \\
\text { Sorell }\end{array}$ & $\begin{array}{l}\text { T: Local government } \\
\text { I: Flinders } \\
\text { M: Latrobe } \\
\text { N: Cradle Coast }\end{array}$ & $\begin{array}{l}12 \text { Nov. 2019, no specimen, P. Collier. } \\
\text { Roadside verge outside private reserve (Rubicon Sanctuary), road } \\
\text { verge kept well slashed through late spring and summer. Single } \\
\text { specimen excavated and disposed of (P. Collier pers. comm.). }\end{array}$ \\
\hline
\end{tabular}


Table 1 cont. - Collection details of all Tasmanian populations of Disa bracteata.

\begin{tabular}{|c|c|c|c|}
\hline Site No. ${ }^{1}$ & Location $^{2}$ & Details $^{3}$ & Comments \\
\hline $5 b$ & $\begin{array}{l}\text { Junction to Squeaking } \\
\text { Point Road, Port Sorell }\end{array}$ & $\begin{array}{l}\text { T: Local government } \\
\text { I: Flinders } \\
\text { M: Latrobe } \\
\text { N: Cradle Coast }\end{array}$ & $\begin{array}{l}4 \text { Nov. 2018, no specimen, P. Collier (pers. comm.). } \\
\text { Grassy roadside, single clumps ( } 3 \text { flower spikes). }\end{array}$ \\
\hline $6 a$ & St Louis Drive, Port Sorell & $\begin{array}{l}\text { T: Private } \\
\text { I: Flinders } \\
\text { M: Latrobe } \\
\text { N: Cradle Coast }\end{array}$ & $\begin{array}{l}20 \text { Nov. 2019, no specimen, S. \& A. Farrelly (via Tasmanian Native } \\
\text { Orchids Facebook page). } \\
\text { Three plants inside property, pulled out and bagged, left in } \\
\text { cupboard and found in mid-2020 - plants had re-sprouted inside } \\
\text { bag, now destroyed in wood heater (S. \& A. Farrelly pers. comm.). }\end{array}$ \\
\hline $6 b$ & St Louis Drive, Port Sorell & $\begin{array}{l}\text { T: Local government } \\
\text { I: Flinders } \\
\text { M: Latrobe } \\
\text { N: Cradle Coast }\end{array}$ & $\begin{array}{l}3 \text { Jan. 2020, no specimen, P. Tonelli (via Tasmanian Native Orchids } \\
\text { Facebook page). } \\
\text { "Whilst collecting dry grass heads (on road side) for my finches in } \\
\text { St Louis Drive, Port Sorell, I spotted a fruiting flower head of the } \\
\text { dreaded/invasive Disa bracteata a species Orchid originally from } \\
\text { South Africa ..then went on to dig out and destroy a dozen + there } \\
\text { must be more I missed!" and "to say there was an 'invasion' would } \\
\text { be an understatement! They were all along the 'nature strip' on both } \\
\text { sides, many have been mown off" (P. Tonelli pers. comm.). }\end{array}$ \\
\hline 7 & $\begin{array}{l}\text { "Badger Head Road, N } \\
\text { side, E of power pole } \\
\text { T6912761A 229117" }\end{array}$ & $\begin{array}{l}\text { T: Local government } \\
\text { I: Flinders } \\
\text { M: West Tamar } \\
\text { N: Cradle Coast }\end{array}$ & $\begin{array}{l}4 \text { Nov. 2014, HO581102, M. Wapstra \& } 13 \text { Oct. 2015, } \\
\text { HO583698. } \\
\text { "Slashed grassy road verge; } 2 \text { in tight clump; both plants were } \\
\text { uprooted" (from HO581102). Refer to Plate } 2 \text { and Plate } 3 . \\
\text { Site re-visited c. } 1 \text { year later and non-fertile individuals from } \\
\text { precisely same patch dug out with spade (M. Wapstra pers. obs.). } \\
\text { Site re-visited } 7 \text { Jul. } 2020 \text { - no signs of re-sprouting (M. Wapstra } \\
\text { pers. obs.). }\end{array}$ \\
\hline 8 & $\begin{array}{l}\text { Turners Beach (Bass } \\
\text { Highway, west of River } \\
\text { Forth) }\end{array}$ & $\begin{array}{l}\text { T: State Growth } \\
\text { I: Northern Slopes } \\
\text { M: Central Coast } \\
\text { N: Cradle Coast }\end{array}$ & $\begin{array}{l}21 \text { Jan. } 2020 \text {, no specimen, C. Broadfield (via Tasmanian Native } \\
\text { Orchids Facebook page). } \\
\text { "Scattered along the roadside bank. At least } 50 \text { but possibly many } \\
\text { more" (C. Broadfield pers. comm.). }\end{array}$ \\
\hline 9 & $\begin{array}{l}\text { Clerke Plains Road, } \\
\text { Spalford }\end{array}$ & $\begin{array}{l}\text { T: Private } \\
\text { I: Northern Slopes } \\
\text { M: Central Coast } \\
\text { N: Cradle Coast }\end{array}$ & $\begin{array}{l}25 \text { Nov. 2019, no specimen, L. Davison (via Tasmanian Native } \\
\text { Orchids Facebook page). } \\
\text { "only about } 3 \text { inches high, first year it's come up. In sand trucked } \\
\text { in to my place from Sassafras about } 10 \text { to } 12 \text { years ago" (L. Davison } \\
\text { pers. comm. } 25 \text { Nov. 2019) \& "it hasn't come back up yet and last } \\
\text { year was the first year" (L. Davison pers. comm. } 7 \text { Aug. 2020). }\end{array}$ \\
\hline 10 & $\begin{array}{l}\text { "S side of Bass Highway" } \\
\text { [between Penguin and } \\
\text { Sulphur Creek] }\end{array}$ & $\begin{array}{l}\text { T: State Growth } \\
\text { I: Northern Slopes } \\
\text { M: Central Coast } \\
\text { N: Cradle Coast }\end{array}$ & $\begin{array}{l}8 \text { Nov. 2011, HO564548, S. Casey. } \\
\text { "Less than } 5 \text { plants were observed; on top of batter with mainly } \\
\text { introduced grasses, but with a few native herbs and orchids" (from } \\
\text { HO564548). } \\
7 \text { Mar. 2016, HO583720, M. Wapstra. } \\
\text { "Grass and weed infested highway batter and flat rise; all individuals } \\
\text { excavated with spade" (from HO583720). } \\
\text { Approximately } 188 \text { individuals were observed along ca. } 200 \text { m } \\
\text { of the highway verge, slope and flat (M. Wapstra pers. obs.). Site } \\
\text { re-assessed on } 31 \text { Oct. } 2017 \text { by M. Wapstra and most plants } \\
\text { marked (all in late bud to very early flower), which was followed by } \\
\text { herbicide application on } 13 \text { Nov. } 2017 \text { (S. Radford pers. comm.). } \\
\text { On } 26 \text { Feb. } 2018 \text {, all plants appeared to be dead, but several had } \\
\text { formed capsules (M. Wapstra pers. obs.). Refer to Plate } 3 \text { and Plate } \\
\text { 5. } \\
\text { On } 7 \text { Nov. } 2019 \text {, the site was re-assessed. Only } 47 \text { individuals } \\
\text { were detected, all hand-pulled (M. Wapstra pers. comm.). Weed } \\
\text { contractor has been advised and has been requested to visit site } \\
\text { at least twice yearly in early-mid Oct. and early to mid Nov. (S. } \\
\text { Leighton, State Growth, pers. comm.). }\end{array}$ \\
\hline
\end{tabular}


Table 1 cont. - Collection details of all Tasmanian populations of Disa bracteata.

\begin{tabular}{|c|c|c|c|}
\hline Site No. ${ }^{1}$ & Location $^{2}$ & Details $^{3}$ & Comments \\
\hline 11 & $\begin{array}{l}\text { Old Stanley Road West, } \\
\text { Smithton }\end{array}$ & $\begin{array}{l}\text { T: Private } \\
\text { I: King } \\
\text { M: Circular Head } \\
\text { N: Cradle Coast }\end{array}$ & $\begin{array}{l}\text { Sep. } 2018 \text {, no specimen, Allison Smith \& Garth Smith (via } \\
\text { Tasmanian Native Orchids Facebook page). } \\
\text { "I photographed it on 11/11/2018. Allison first spotted it about } 2 \\
\text { or } 3 \text { weeks before I posted it in the FB orchid page asking for ID. } \\
\text { So she first spotted it approximately the last week of September. } \\
\text { We only saw one that year, and that was the same one, that after } \\
\text { discussion with you, Allison bagged and monitored, and saw it try } \\
\text { to keep growing. The next year (Nov 2019) we monitored the spot } \\
\text { and saw nothing in that spot. We monitored it quite regularly as } \\
\text { there are T. pauciflora in the near vicinity that I was keeping an eye } \\
\text { on to photograph. We will monitor it and the immediate surrounds } \\
\text { again this year and in subsequent years. The spot it was growing is } \\
\text { remnant coastal dune from when the sea level was a lot higher" (G. } \\
\text { Smith pers. comm.). }\end{array}$ \\
\hline 12 & Musselroe area & $\begin{array}{l}\text { T: Private } \\
\text { I: Flinders } \\
\text { M: Dorset } \\
\text { N: North }\end{array}$ & $\begin{array}{l}12 \text { Nov. 2013, no specimen, G. Daniels. } \\
\text { Re-visited mid-November 2015, with intent to excavate single plant } \\
\text { originally observed, but could not be re-found (G. Daniels per. } \\
\text { obs.). Refer to Plate } 4 \text {. }\end{array}$ \\
\hline 13 & $\begin{array}{l}\text { Orchard Avenue, } \\
\text { Huonville }\end{array}$ & $\begin{array}{l}\text { T: Private } \\
\text { I: Southern Ranges } \\
\text { M: Huon Valley } \\
\text { N: South }\end{array}$ & $\begin{array}{l}20 \text { Nov. 2019, iNaturalist, M. Storer. } \\
\text { "29 individual plants. Dug out (with tubers) on 9/12/2019". }\end{array}$ \\
\hline
\end{tabular}

1 Site no. cross-references to fig. 2.

2 Location name in " ” as per HO record.

3 T - Tenure; I - Interim Biogeographic Regionalisation for Australia (IBRA) Region; M - Municipality; N - Natural Resource Management Region.

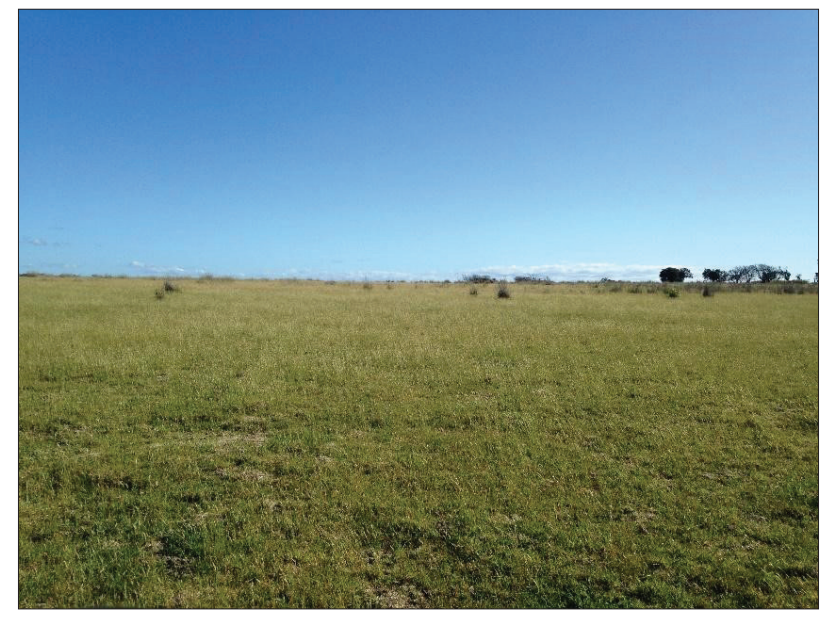

PLATE 4 - Habitat of Disa bracteata at Musselroe. (Image: G. Daniels)

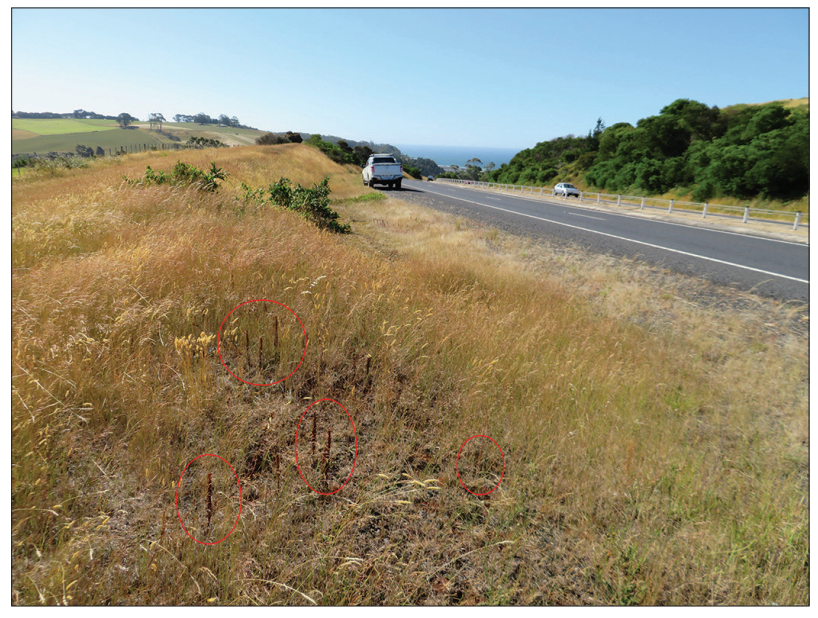

PLATE 5 - Habitat of Disa bracteata near Burnie on Bass Highway, with several individuals gone to seed in the foreground, circled. (Image: M. Wapstra) 


\section{RESULTS}

The first record of D. bracteata in Tasmania was in 2005 (fig. 2, table 1), 61 years after it was first detected in Western Australia in 1944. Since then, it has been reported from several additional Tasmanian sites (fig. 2, table 1).

The species is now known from all three Natural Resource Management (NRM) regions; the Dorset, Latrobe, West Tamar, Central Coast, Circular Head and Huon Valley municipal areas; and the Flinders, Northern Slopes, King and Southern Ranges IBRA regions (defined in Environment Australia 2000).

The species has a linear range in Tasmania of ca. $255 \mathrm{~km}$ (from Smithton to Musselroe) or ca. $190 \mathrm{~km}$ (Smithton to Huonville). Until the discovery of the species in Huonville, $D$. bracteata had a predominantly near-coastal distribution in northern Tasmania. Within Tasmania, $D$. bracteata has been collected from disturbed sites (e.g. waste ground around Latrobe), roadside verges (Badger Head Road, Parkers Ford Road, Bridport Road, Bass Highway), rough pasture (Musselroe), and urban-rural living habitats (Spreyton, Port Sorell, Huonville). The verges of several road sites supporting the species are frequently mown/slashed, meaning that the species may have gone undetected for a period, and this is a likely mechanism for localised dispersal.

\section{DISCUSSION}

$D$. bracteata has made a progressive easterly 'march' across Australia since first being detected in Western Australia. Once in Victoria, evidence indicates it has freely spread through that state, and the arrival of the species in Tasmania seemed almost inevitable. Multiple easterly incursions from Western Australia into eastern states may have occurred, although this is conjecture. While the arrival in Tasmania is a relatively recent event, it has not taken long for the species to become widespread across the north coast, and more recently further afield in southern Tasmania.

Due to its early phase of establishment, D. bracteata is not perceived to be causing significant negative impacts in Tasmania at this time. In other states, the species has spread rapidly and covered large areas of extent (geographic range) and areas of occupancy (has colonised significant tracts of land). On mainland Australia, the species is a recognised threat to several nationally threatened orchid species (Commonwealth of Australia 2018), for example, Thelymitra matthewsii Cheeseman (Duncan 2010). In Tasmania, several sites with $D$. bracteata are close to habitats supporting threatened orchid species and weed invasion is already a recognised threat to Tasmania's native orchids (TSS 2017).

The species is accepted as being fully naturalised in Tasmania (de Salas \& Baker 2019). Large parts of Tasmania are climatically suitable, and it is hoped that the apparent lack of records for most of the state represents a genuine absence rather than the species being overlooked. We postulate that there is a genuine risk of $D$. bracteata spreading further in Tasmania over the coming decades.
Understanding and predicting biological invasion processes is a valuable tool to anticipate ecological, economic and social impacts, and in some cases to enact fast response actions for biodiversity conservation (e.g. Pertierra et al. 2016, Pertierra et al. 2017). Konowalik and Kolanowska (2018) undertook ecological niche modelling on $D$. bracteata. They found that most of the accessible areas are already occupied by this species, but future expansion will continue based on different climate change scenarios, with further expansion predicted especially in eastern Australia and eastern Tasmania.

The future spread of $D$. bracteata in Tasmania is likely to be into primary production areas, such as grazing/ cropping land and possibly commercial forestry plantations (where it occurs in other states), and parts of the formal conservation reserve system. Of most concern is that three of the known sites are close to conservation areas (Musselroe Bay Conservation Area, Rubicon Sanctuary private reserve and Narawntapu National Park). Unlike many native orchid species, Disa bracteata has less specific fungal associations (Bonnardeaux et al. 2007) and this may facilitate its weed-like colonisation of disturbed sites (Grant \& Koch 2003, Collins et al. 2005, De Long et al. 2013). Climate change may increase the availability of climatically suitable areas for invasion in Tasmania, particularly at higher elevations. However, even with long-term change, the risk of expansion into the higher rainfall parts of the state, such as the extensive southwest Tasmanian Wilderness World Heritage Area is probably low. Globally non-indigenous orchids appear to present a relatively low risk of impact on natural processes but some localised impacts are recognised (Recart et al. 2013).

To date, detections of $D$. bracteata have all been serendipitous, and a result of vigilant observers or during ecological assessments for development proposals (e.g., road widening projects). For most of the year, the species is undetectable, surviving as underground tubers buried below dense grass (plate 2, plate 3 ). While the leaves are distinctive, a small patch would be easily overlooked or mistaken for other weeds such as young plants of the common and widespread Tragopogon porrifolius L. (salsify). It is only once the flowering spike emerges that is more easily detected (and then only usually if the surrounding vegetation has been mown). Targeted surveys of potential habitat (mainly road verges in Tasmania) would be resourcehungry, likely to be 'hit and miss' due to seasonal variations in population emergence and abundance as well as great variability in detectability due to mowing/slashing/herbicide regime, and even then would possibly require complex traffic management to facilitate surveys.

Disa bracteata may warrant listing as declared under the provisions of the Tasmanian Weed Management Act 1999 as it may have an adverse impact on natural resources and maintenance of indigenous ecological processes in Tasmania. If listed as a declared species on the Tasmanian Weed Management Act 1999, Zone A is the classification most applicable to $D$. bracteata for all municipalities. This would mean eradication is the key objective, which we believe should be the short- and long-term management 
objective in Tasmania. Efforts to eradicate the species from Latrobe, Bridport Road, Badger Head Road and Parkers Ford Road have been implemented (all by manual excavation of whole plants including tubers and roots). However, the species was re-detected the year after the first excavation of tubers from the Badger Head Road site (M. Wapstra per. obs.). The status of the population near Bridport (the site of original detection of the species in 2005) was uncertain for many years, until observed again in 2016; annual control commenced with its rediscovery (as well as new observations of local sub-populations) but will need to continue for several years after over 500 plants were observed in one season (following excavation efforts the previous year). Despite apparent eradication from the Latrobe site at the time of detection, the species was refound in the general region (Spreyton) in subsequent years, suggesting further populations may have gone undetected and that propagule pressure from external sources (such as vehicles arriving on mainland ferry services) may result in continual reintroductions at suitable locations. Searches for the species at the Musselroe site in 2015 failed to detect it, possibly meaning it is now absent from there, although no intervention has occurred and the prolonged absence at Bridport after the initial detection suggests that when local populations are establishing the species may not be detectable every year. The population along the Bass Highway near Burnie was manually removed in November 2017 and will continue to be monitored (S. Radford pers. comm.). Treatment at this site has already reduced the number of individuals by more than 75\% (M. Wapstra pers. obs.). The distribution of populations in the Port Sorell area suggest that roadside slashing and residential development is actively encouraging the spread of the species. This means that while the long-term management objective should ideally be eradication, in practice this may become containment within the intent of the Tasmanian Weed Management Act 1999.

While the recent spread of the species appears to indicate an almost inevitable slow march of $D$. bracteata across suitable parts of Tasmania, it has been effectively eradicated from several sites by early intervention. This provides hope that, with continued vigilance and active management, $D$. bracteata may remain widespread but only as a sparingly naturalised species.

\section{ACKNOWLEDGEMENTS}

We thank Peter Tonelli, Stephen Casey, Andrew North, Karen Ziegler, Phil Collier, Craig Broadfield, B.J. Green, Grace Pocknee, Steph \& Andrew Farrelly, Garth Smith, Allison Smith and Michelle Storer for discussions regarding their observations of D. bracteata. Jillian Jones (Department of State Growth) and Shane Radford (Coastal Landcare Services) provided information on the control of the population near Burnie. Glenn Wardle provided information and data on the control and status of the Bridport population. Thanks go to David Jones, Gintaras Kantvilas and Lorilee Yeates for their helpful comments on drafts of this manuscript. Two referees (Joe Quarmby and Karen Stewart) provided useful commentary that improved the manuscript.

\section{REFERENCES}

Ackerman, J. 2007: Invasive orchids: weeds we hate to love? Lankesteriana 7(1-2): 19-21.

ALA (Atlas of Living Australia) 2020: Occurrence records, https://biocache.ala.org.au/occurrences/search?q $=1$ sid $\% 3 \mathrm{Ahttps} \% 3 \mathrm{~A} \% 2 \mathrm{~F} \% 2 \mathrm{Fid}$.biodiversity.org. au\%2Fname\%2Fapni\%2F190752 (accessed 19 August 2020).

AVH (Australasian Virtual Herbarium) 2020: Occurrence records, https://avh.ala.org.au/occurrences/search?q=1sid\%3Ahtt ps\%3A\%2F\%2Fid.biodiversity.org.au\%2Fname\%2Fap ni\%2F190752\&qc=data_hub_uid\%3Adh9 (accessed 19 August 2020).

Bonnardeaux, Y., Brundrett, M., Batty, A., Dixon, K., Koch, J. \& Sivasithamparam, K. 2007: Diversity of mycorrhizal fungi of terrestrial orchids: compatibility webs, brief encounters, lasting relationships and alien invasions. Mycological Research 111: 51-61.

Breitwieser, I., Brownsey, P.J., Heenan, P.B., Nelson, W.A. \& Wilton, A.D. (eds) 2018: Flora of New Zealand Online - Taxon Profiles, http:/www.nzflora.info/factsheet/Taxon/ Orchidaceae.html (accessed 30 March 2018).

Chen, X., Liu, Z., Zhu, G., Lang, K., Ji, Z., Luo, Y., Jin ,X., Cribb, P.J., Wood, J.J., Gale, S.W., Ormerod, P., Vermeulen, J.J., Wood, H.P., Clayton, D. \& Bell, A. 2009: Orchidaceae. In Wu, Z.Y, Raven, P.H. \& Hong, D.Y. (eds): Flora of China. Vol. 25 (Orchidaceae). Science Press, Beijing \& Missouri Botanical Garden Press: St Louis: 584 pp.

Clements, M. \& Jones, D.L. 2008: Australian Orchid Name Index (13/6/2008), http://www.anbg.gov.au/cpbr/cd-keys/ orchidkey/Aust-Orch-Name-Index-08-06-13.pdf, (accessed 30 March 2018).

Collins, M., Koch, J., Brundrett, M. \& Sivasithamparam, K. 2005: Recovery of terrestrial orchids in the post-mining landscape. Selbyana 26(1/2): 255-264.

Commonwealth of Australia 2018: Species Profile and Threats Database. Australian Government, Department of the Environment and Energy, http://www.environment.gov.au/ cgi-bin/sprat/public/sprat.pl. (accessed 19 August 2020).

Conran, J., Maciunas, E. \& Maciunas, K. 2011: Serapias lingua L. (tongue orchid): naturalised in the Adelaide Hills, South Australia - caveat cultivator? The Orchadian 16(12): 556-561.

De Long, J.R., Swarts, N.D., Dixon, K.W. \& Egerton-Warburton, L.M. 2013: Mycorrhizal preference promotes habitat invasion by a native Australian orchid: Microtis media. Annals of Botany 111: 409-418.

de Salas, M.F. \& Baker, M.L. 2019: A Census of the Vascular Plants of Tasmania, including Macquarie Island. Tasmanian Herbarium, Hobart: 156 pp.

DPIPWE (Department of Primary Industries, Parks, Water \& Environment) 2020: Natural Values Atlas, www. naturalvaluesatlas.tas.gov.au (accessed 8 August 2020).

Duncan, M. 2010: National Recovery Plan for the Spiral Sun Orchid Thelymitra matthewsii. Department of Sustainability \& Environment, Melbourne: 11 pp.

Environment Australia 2000: Revision of the Interim Biogeographic Regionalisation for Australia (IBRA) and Development of Version 5.1 - Summary Report. Department of Environment and Heritage, Canberra: $36 \mathrm{pp}$.

Gardner, R.O. \& de Lange, P.J. 1996: Naturalised plants in New Zealand: new or noteworthy records. Auckland Botanical Society Journal 51(2): 74-77. 
Goldblatt, P. \& Manning, J. 2000: Cape Plants: A conspectus of the Cape flora of South Africa, (Strelitzia 9). National Botanic Institute of South Africa, Pretoria and Missouri Botanical Garden Press, St Louis: 744 pp.

Grant, C.D. \& Koch, J. 2003: Orchid species succession in rehabilitated bauxite mines in Western Australia. Australian Journal of Botany 51: 453-457.

Howell, C. \& Sawyer, J.W.D. 2006: New Zealand Naturalised Vascular Plant Checklist. New Zealand Plant Conservation Network, Wellington: 60 pp.

Jones, D.L. 2006: A Complete Guide to Native Orchids of Australia including the Island Territories. Reed New Holland, Sydney: 496 pp.

Konowalik, K. \& Kolanowska, M. 2018: Climatic niche shift and possible future spread of the invasive South African orchid Disa bracteata in Australia and adjacent areas. PeerJ 6: e6107 http://doi.org/10.7717/peerj.6107

Leistner, O.A. (ed.) 2000: Seed plants of Southern Africa: families and genera. (Strelitzia 10). National Botanical Institute, Pretoria: 776 pp.

Linder, H.P. 1981: Taxonomic studies in the Disinae. V. A revision of the genus Monadenia. Bothalia 13(3 \& 4): 339-363.

Mabberley, D.J. 2008: Mabberley's Plant-Book: A Portable Dictionary of Plants, Their Classification and Uses. Third edition. Cambridge University Press, Cambridge: 1021 pp.

Pertierra, L.R., Baker, M., Howard, C., Vega, G.C., OlallaTarraga, M.A. \& Scott, J. 2016: Assessing the invasive risk of two non-native Agrostis species on sub-Antarctic Macquarie Island. Polar Biology 39(12): 2361-2371.
Pertierra, L.R., Aragón, P., Shaw, J.D., Bergstrom, D.M., Terauds, A. \& Olalla-Tarraga, M.A. 2017: Global thermal niche models of two European grasses show high invasion risks in Antarctica. Global Change Biology 23(7): 2863-2873.

Recart, W., Ackerman, J.A. \& Cuevas, A.A. 2013: There goes the neighborhood: apparent competition between invasive and native orchids mediated by a specialist florivorous weevil. Biological Invasions 15: 283-293.

Richardson, F.J., Richardson, R.G. \& Shepherd, R.C.H. (2016). Weeds of the South-East: An Identification Guide for Australia. R.G. and F.J. Richardson, Meredith: 522 pp.

Rupp, H.M.R. 1947: Two new orchids from Western Australia. Australian Orchid Review 11: 70.

Scott, J.K. \& Delfosse, E.S. 1992: Southern African plants naturalised in Australia: a review of weed status and biological control potential. Plant Protection Quarterly 7: 70-80.

Scott, J.K. \& Panetta, F.D. 1993: Predicting the Australian weed status of Southern African plants. Journal of Biogeography 20(1): 87-93.

Synge, P.M. (ed.) 1977: Dictionary of Gardening A Practical and Scientific Encyclopedia of Horticulture. Second Edition. Oxford University Press, Oxford: $2316 \mathrm{pp}$.

TSS (Threatened Species Section) 2017: Threatened Tasmanian Orchids Flora Recovery Plan. Department of Primary Industries, Parks, Water \& Environment, Hobart: 95 pp.

(Accepted 12 October 2020) 